\title{
Analysis of the mitotic index of chicken primordial germ cells before and after settling in the germinal ridge
}

\author{
T. Maeda \\ Faculty of Applied Biological Science, Hiroshima University, Higashi-Hiroshima, 739-8528, Japan
}

\begin{abstract}
The mitotic index of chicken primordial germ cells was determined by analysing the nuclear DNA content and the number of $M$ phase and S phase primordial germ cells at stage 14-15 (before settling in the germinal ridge) and at stage 17-18 (after settling in the germinal ridge) using an interactive laser cytometer. When nuclear DNA content was presented graphically, two peaks were revealed at each of the two stages being studied. The value of the second peak was approximately twice that of the first peak. Primordial germ cells, having two nuclei in one cell, were recognized at each stage and were considered to be at $M$ phase in cell division. The amount of nuclear DNA in both $S$ and $M$ phases was correlated with that between the first and the second peaks and that in the second peak, respectively. The number of $M$ phase and $S$ phase primordial germ cells significantly increased after they had settled in the germinal ridge. These results suggest that chicken primordial germ cells start to proliferate actively as soon as they reach the gonadal ridge.
\end{abstract}

\section{Introduction}

Several studies have been carried out to show the proliferation or differentiation of gonadal germ cells in chick embryos. Hughes (1963) reported that the total population of germ cells in the left ovarian cortex increased about twenty-five-fold between 9 and 17 days of incubation. It has also been reported that the number of germ cells in male and female left gonads increases regularly between 2 and 17 days of incubation (Erickson, 1974a,b; Vallisneri et al., 1990). Swartz and Domm (1972) demonstrated that the number of germ cells increased from 43 at $18 \mathrm{~h}$ of incubation to 2211 at $120 \mathrm{~h}$ of incubation, and that two periods of intense proliferation were observed, the first between 48 and $72 \mathrm{~h}$, the second between 96 and $120 \mathrm{~h}$.

Studies on the origin, ultrastructure and DNA quantity of primordial germ cells (PGCs) in early chick embryos have suggested that PGCs originate in the epiblast, that their size and structure change with the advancing stage in development, and that there is a periodic change of DNA in the nuclei of PGCs circulating in the vascular system. Furthermore, it has been suggested that PGCs with high fluorescence splitting into two parts be considered to be at $M$ phase of cell division, and that analysis of nuclear DNA quantity and frequency of $M$ phase in PGCs might prove practical and useful in determining the mitotic index of PGCs (Maeda and Terada, 1997).

5 -Bromodeoxyuridine (BrdU) is a thymidine (Thy) analogue that is incorporated into the nuclear DNA during the $S$ phase of the cell cycle. Cell nuclei that have incorporated BrdU can be detected by monoclonal antibodies and immunocytochemistry (Gratzner, 1982). The immunocytochemical visualization of BrdU is used in studies of cell kinetics (Hoshino et al., 1985; Pallavicini et al., 1985; Soriano and Del Rio, 1991; Casasco et al.,

Received 14 August 1997.
1995); therefore, it should be appropriate to use BrdU immunohistochemistry to judge the mitotic index of PGCs.

In the present study, the nuclear DNA content of PGCs and the number of cells at the $M$ phase and $S$ phase at stage 14-15 and at stage 17-18 were analysed using an interactive laser cytometer to determine the mitotic index of PGCs before and after settling in the germinal ridge.

\section{Materials and Methods}

\section{Collection and handling of samples from embryos}

Fertile Leghorn eggs were obtained from a local commercial poultry breeder. Thirty eggs were incubated for $50-67 \mathrm{~h}$ at $37.5^{\circ} \mathrm{C}$ and a relative humidity of $60 \%$. The incubated eggs were cracked on Petri dishes. All embryos were dissected free from the yolk, transferred to another dish containing Dulbecco's PBS ( $\mathrm{pH} 7.4$ ) and observed under a stereomicroscope to examine the stage of development. The classification of embryonic stages was that described by Hamburger and Hamilton (1951). Blood samples from the stage 14-15 embryos were collected by tearing the vitelline artery with two pins, and were aspirated with a micropipette. Embryonic bodies at stage 17-18 were picked up and transferred to another Petri dish containing PBS. Tissues around and including the germinal ridge were dissected out of at least five embryos with a pair of small scissors, placed in a microfuge tube $(2.0 \mathrm{ml}$ capacity) containing $0.5 \mathrm{ml}$ PBS supplemented with $0.25 \%(\mathrm{w} / \mathrm{v})$ trypsin (Biozyme, Gwent) and $0.02 \%(w / v)$ EDTA (Katayama Chemical Industries, Osaka), and then incubated at $38^{\circ} \mathrm{C}$ for $10 \mathrm{~min}$. The enzyme reaction was stopped by adding $1.5 \mathrm{ml}$ PBS containing $10 \%$ chicken serum and mixing with a Vortex mixer (Scientific Industries Inc., Bohemia, NY) for $2 \mathrm{~min}$. After centrifugation at 
$200 \mathrm{~g}$ for $5 \mathrm{~min}$, the pellets were dispersed in $\mathrm{I} \mathrm{ml} \mathrm{PBS}$ including $0.02 \%(\mathrm{w} / \mathrm{v})$ EDTA, incubated for $10 \mathrm{~min}$, and then mixed again by a Vortex mixer for 2 min. After further centrifugation at $200 \mathrm{~g}$ for $5 \mathrm{~min}$, the pellets were washed with $1 \mathrm{ml}$ PBS.

\section{Immunocy tochemistry for bromodeoxyuridine}

The blood samples from the stage 14-15 PGCs and separated samples from the stage 17-18 PGCs were washed and incubated with minimum essential medium (MEM; Gibco BRL, Grand Island, NY) supplemented with $10 \mu \mathrm{mol} \mathrm{BrdU} \mathrm{l^{-1 }}$ (Sigma Chemical Co., St Louis, MO) and 10\% fetal calf serum (Gibco) for $1 \mathrm{~h}$ at $37^{\circ} \mathrm{C}$. The samples were fixed by methanolacetic acid for $30 \mathrm{~min}$ and treated with Triton-X100 (Nacalai Tesque, Kyoto) for 10 min to aid permeability of the following antibody. After washing with PBS, the samples were reacted with monoclonal anti-BrdU antibody labelled with fluorescein isothiocyanate (FITC; Oncogene Science Inc., Uniondale, NY), washed a further three times with PBS, smeared on glass slides coated with $2 \%(\mathrm{v} / \mathrm{v}) 3$-aminopropyltriethoxysilane (Sigma), and then dried. Specificity for monoclonal anti-BrdU antibody was demonstrated using control samples prepared in the same manner; however, the control samples were incubated with MEM without BrdU.

\section{Methods of staining of primordial germ cells}

After drying, the samples from blood and embryonic tissues were stained by the periodic acid-Schiff technique (PAS) to identify the primordial germ cells (Meyer, 1964). After PAS staining, samples were overlaid with $1 \mathrm{mg}$ ribonuclease $\mathrm{A}$ $\mathrm{ml}^{-1}$ (Sigma) solution and incubated at $37^{\circ} \mathrm{C}$ for $30 \mathrm{~min}$ to prevent propidium iodide from reacting to $\mathrm{RNA}$ in the cytoplasm of cells. The cells were sealed with $20 \mu \mathrm{g}$ propidium iodide $\mathrm{ml}^{-1}$ (Sigma) to stain their DNA. The cells with dark staining bodies (magenta with the PAS reaction) were observed under a microscope and analysed using an interactive laser cytometer (ACAS 570 Equipment, Meridian Instruments Inc., Okemos, MI).

\section{Observational conditions of the laser cytometer}

An object lens of the laser cytometer was used at a magnification of $\times 100$. The excitation was blue colour with $488 \mathrm{~nm}$ emission. The wavelength of the detectors was 530 (measurement of FITC fluorescence) and $630 \mathrm{~nm}$ (measurement of propidium iodide fluorescence). The diameter of the iris pinhole was $22.27 \mu \mathrm{m}$ and the area of measurement for each PGC was $1296 \mu \mathrm{m}^{2}$. The scanning strength of the laser was $10 \%$, the speed of scanning was $0.5 \mathrm{~mm} \mathrm{~s}^{-1}$ and the laser power was $200 \mathrm{~mW}$.

\section{Analysis of nuclear DNA content}

First, the background volumetric fluorescence of each glass without cells was measured. After this measurement, the sensitivity of the detector (the percentage of maximum voltage applied to the detector to unify the background fluorescence) was varied from 16.0 to $17.2 \%$. DNA fluorescent strength was expressed in different colours and colour values, and the colour values increased in proportion to the DNA content (Fig. Ia,b,c). The fluorescence image of each PGC was merged into a transmission image to determine the position of the nucleus (Fig. 1a). The value of the boundary between the nucleus and the cytoplasm was estimated at about 1535 arbitrary fluorescence units from this image (arrows in Fig. Ia,b,c). Colour values of $>1535$ were summed automatically by the ACAS 570 equipment to give a value for the nuclear DNA content (expressed in arbitrary fluorescence units).

\section{Statistical analysis}

Data from two replicates were pooled, and significant differences were determined by the chi-squared test.

\section{Results}

Primordial germ cells were identified easily by PAS staining. Most PGCs from each stage of embryonic development had generally round large nuclei with a highly fluorescent area indicating propidium iodide reaction to cell DNA (Fig. 1a). The fluorescent areas on the images produced resembled the contour lines of a mountain (Fig. Ia); however, some possessed two highly fluorescent areas in one cell, and these were considered to be at the $\mathrm{M}$ phase of cell division (Fig. 1b,c). As BrdU is used to synthesize DNA, PGCs with FITC fluorescence (arrow in Fig. Id) were considered to be at the $\mathrm{S}$ phase of cell division (Fig. Id). No FITC fluorescence was seen in control samples.

When nuclear DNA content was presented graphically, two peaks were recognized at each of the two stages being studied. In embryos at stage 14-15, the first (large arrow in Fig. 2a) and second peak (small arrow in Fig. 2a) were approximately $9 \times 10^{6}$ and $22 \times 10^{6}$ arbitrary fluorescence units, respectively. In embryos at stage 17-18, the first (large arrow in Fig. 2b) and second peak (small arrow in Fig. 2b) were approximately $8 \times 10^{6}$ and $18 \times 10^{6}$ arbitrary fluorescence units, respectively. The value of the second peak was approximately twice that of the first peak. The nuclear DNA in cells at the $S$ phase was located between the two peaks. The nuclear DNA in cells at the $M$ phase was located around the second peak. The number of $\mathrm{M}$ phase and $\mathrm{S}$ phase primordial germ cells significantly increased after they had settled in the germinal ridge (Table 1).

\section{Discussion}

The early methods for cell-cycle analysis were based on the use of ${ }^{3} \mathrm{H}$ - or ${ }^{14} \mathrm{C}$-labelled Thy followed by the detection of this precursor upon its incorporation into cellular DNA by autoradiography (Howard and Pelc, 1953). The detection of BrdU incorporation by flow cytometry, which identifies the cells replicating DNA, was a powerful alternative to $\left[{ }^{3} \mathrm{H}\right]$ Thy autoradiography and has been recommended for use in studies of cell kinetics, both in cultures and in experiments in vivo (Gratzner, 1982; Moran et al., 1985; De Fazio ef al., 1987; Plickert and Kroiher, 1988; Watanabe and Raff, 1988). In the 

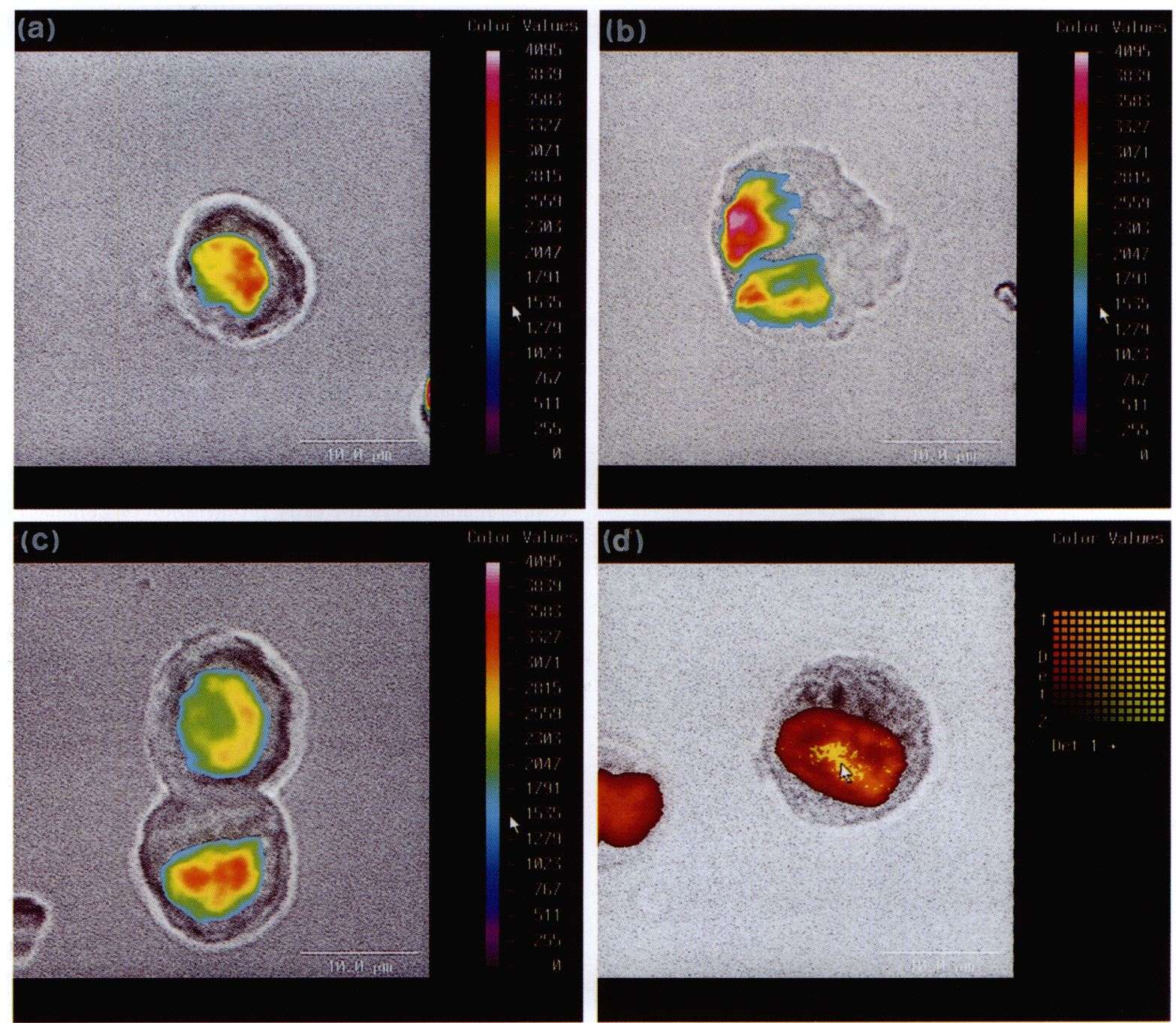

Fig. 1. (a) Fluorescent image of a chicken primordial germ cell resembling the contour lines of a mountain. (b,c) Chicken primordial germ cells at the $\mathrm{M}$ phase with two highly fluorescent areas in one cell. Note the boundary value between the nucleus and the cytoplasm (arrows). (d) Chicken primordial germ cell at the S phase with fluorescein isothiocyanate fluorescence (arrow) in the nucleus. Scale bars represent $10 \mu \mathrm{m}$.

present study, PGCs that had incorporated BrdU were detected by an interactive laser cytometer, and nonspecific labelling in nuclei for monoclonal anti-BrdU antibody was demonstrated using control samples incubated with MEM without BrdU. The results of the present study and the reports mentioned above suggest that this method of labelling DNA replication with BrdU followed by immunohistochemical visualization is a practical and useful tool in the analysis of the mitotic index of cells in early chick embryo.

Estimation of the stage of cell cycle on the basis of DNA content is possible using flow cytometry analysis because nuclear DNA content increases during the $S$ phase and, therefore, the amount of DNA doubles in the G2 and M phases (Darzynkiewicz, 1993). However, a problem with flow cytometry is that the cells being studied are present alongside other cells (in the present study, PGCs were present alongside somatic cells). In the present study, when the nuclear DNA content was presented graphically, two peaks were revealed at both stages being studied. Moreover, the value of the second peak was approximately twice that of the first peak. Therefore, it seems that when there are few cells and the particular cells being studied are present alongside other cells, the measurement of DNA content by a laser cytometer is a more useful method than analysis by flow cytometry. However, in the present study, the two peaks were dissimilar, in that the first and second peaks were $9 \times 10^{\circ}$ and $22 \times 10^{\circ}$ in stage $14-15$ embryos, and $8 \times 10^{6}, 18 \times 10^{\circ}$ in stage 17-18 embryos, respectively. A greater number of PGCs may need to be analysed to get similar values at both stages.

In terms of cellular DNA content distribution, Darzynkiewicz (1993) suggested that the stage of a cell in the cell cycle can be estimated by measurement of its DNA content. Since the duration of the S, G2 and M phases of the cell cycle is relatively constant while the duration of GI varies, the sum of cells in S, G2 and M phases reflects the mitotic index of the cell population. If cell division occurs, the numbers of cells at the G1 phase will decrease, while those at the S, G2 or $\mathrm{M}$ phase will increase. 


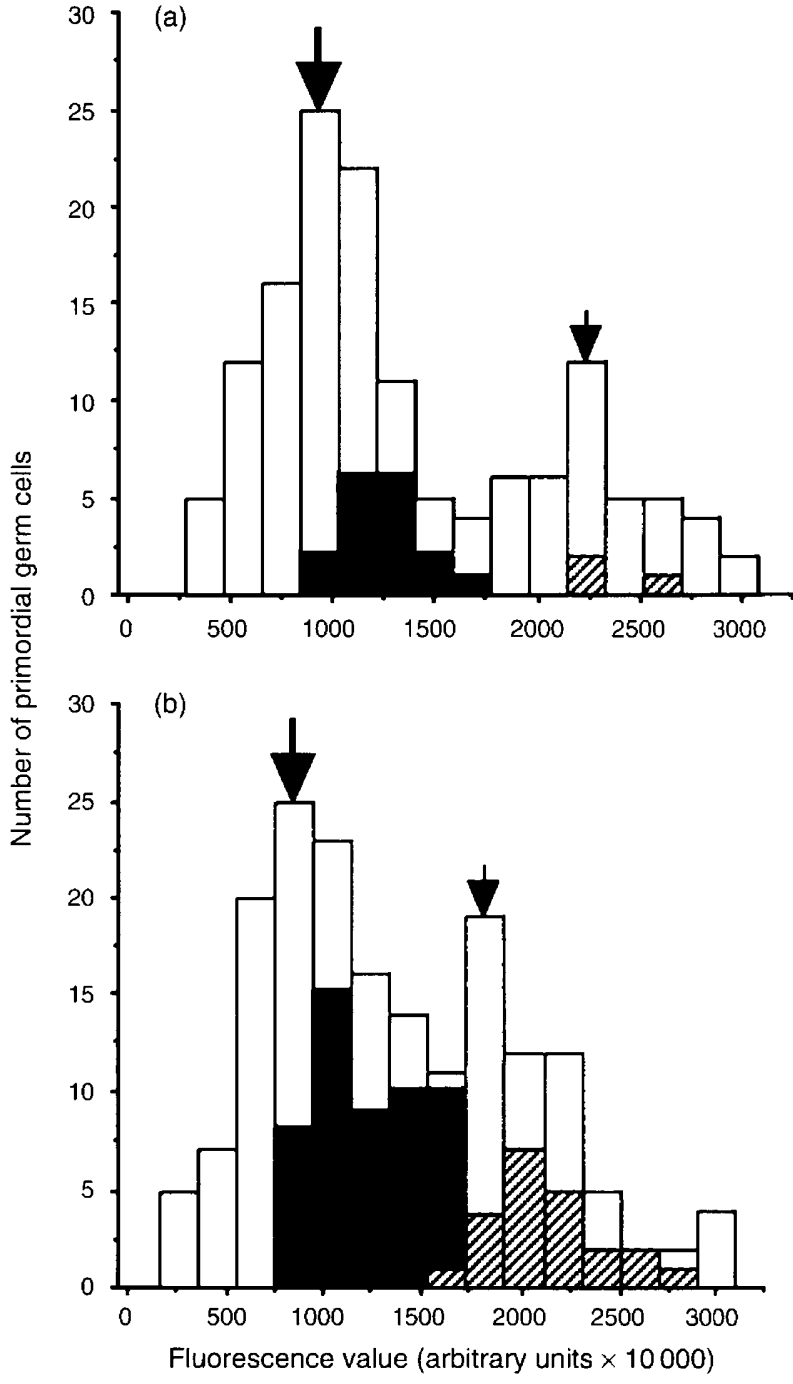

Fig. 2. Nuclear DNA content in chicken primordial germ cells at (a) stage 14-15 and (b) stage 17-18. Note the first (large arrows) and second peaks (small arrows). $\square, G 1$ or G2 phase; $\mathbf{S}$ phase; $\oslash$, M phase.

In the present study, the proportion of PGCs undergoing proliferation (the proportion of cells at either the $S$ phase or the $M$ phase) was greater at stage 17-18, which is the period immediately after PGCs reached the gonadal ridge, than at stage 14-15, when PGCs circulate within the vascular system together with blood cells. This finding suggests that PGCs start to proliferate actively as soon as they reach the gonadal ridge. Swartz and Domm (1972) reported that the mean number of PGCs increased significantly at $72 \mathrm{~h}$ (stage 17) and that the peak in the number of PGCs between 48 and $72 \mathrm{~h}$ (stages 9-14) was accompanied by a simultaneous increase in the number of mitotic cells. Moreover, Simkiss et al. (1993) suggested that PGCs proliferate rapidly and differentiate into germ cells after their settlement in the germinal ridge. Statistical analyses of the number and dimensions of PGCs in chick embryos after 2-7 days incubation have indicated that the numerical increase of the PGCs occurs earlier in females than it does in males (Vallisneri et al., 1990). Therefore, further
Table 1. Number of chicken primordial germ cells at the $S$ phase and $\mathrm{M}$ phase of cell division before and after settling in the germinal ridge

\begin{tabular}{lccc}
\hline Embryonic stage & $\begin{array}{c}\text { Number } \\
\text { of cells } \\
\text { analysed }\end{array}$ & $\begin{array}{c}\text { Number } \\
\text { of cells at } \\
\text { S phase (\%) }\end{array}$ & $\begin{array}{c}\text { Number } \\
\text { of cells at } \\
\text { M phase (\%) }\end{array}$ \\
\hline $\begin{array}{c}14-15 \text { (before settling } \\
\text { in the germinal ridge) }\end{array}$ & 140 & $17(12.1)^{\mathrm{a}}$ & $3(2.1)^{\mathrm{a}}$ \\
$\begin{array}{c}17-18 \text { (after settling } \\
\text { in the germinal ridge) }\end{array}$ & 177 & $51(28.8)^{\mathrm{b}}$ & $22(12.4)^{\mathrm{b}}$ \\
\hline
\end{tabular}

${ }^{a b}$ Different superscripts within the same column represent significant differences $(P<0.01)$.

temporal analysis of the early proliferation of gonadal PGCs in chick embryos of known sex is recommended.

Simkiss et al. (1993) also stated that PGCs contain membrane receptors of growth factors and that both the direction of migration to the germinal ridge and subsequent proliferation are probably directed by growth factors. Therefore, the intense proliferation of PGCs after settlement in the germinal ridge may be attributed to such growth factors.

The author is grateful to R. J. Etches, Department of Animal and Poultry Science, University of Guelph, Canada, for advice and for kindly reviewing the manuscript.

\section{References}

Casasco A, Casasco M, Cornaglia AI, Mazzini G, De Renzis R and Tateo S (1995) Detection of bromo-deoxyuridine and proliferating cell nuclear antigenimmunoreactivities in tooth germ Connective Tissue Research 32 63-70

Darzynkiewicz Z (1993) Mammalian cell-cycle analysis. In The Cell Cycle: A Practical Approach pp 45-68 Eds P Fantes and R Brooks. Oxford University Press, New York

De Fazio A, Leary JA, Hedley DW and Tattersall MHN (1987) Immunohistochemical detection of proliferating cells in vivo. Journal of Histochemistry and Cytochemistry 35 571-577

Erickson GF (1974a) 'Spontaneous' sex reversal in organ cultures of the embryonic male gonad of the bird Journal of Embryology and Experimental Morphology $31611-620$

Erickson GF (1974b) The control of the differentiation of female embryonic germ cells in the bird Developmental Biology 36 113-129

Gratzner HG (1982) Monoclonal antibody to 5-bromo- and 5-iododeoxyuridine: a new reagent for detection of DNA replication Science 218 $474-475$

Hamburger $\mathrm{V}$ and Hamilton HL (1951) A series of normal stages in the development of the chick embryo Journal of Morphology 88 49-92

Hoshino T, Nagashima T, Murovic J, Levin EM, Levin VA and Rupp SM (1985) Cell kinetic studies of in situ human brain tumors with bromodeoxyuridine Cytometry 6 627-632

Howard A and Pelc SR (1953) Synthesis of desoxyribonucleic acid in normal and irradiated cells and its relation to chromosome breakage Heredity Supplement $6261-273$

Hughes GC (1963) The population of germ cells in the developing female chick Journal of Embryology and Experimental Morphology 11 513-536

Maeda T and Terada T (1997) Studies on the origin, ultrastructure and DNA quantity of primordial germ cells in early chick embryo Japanese Poultry Science 34 27-35

Meyer DB (1964) The migration of primordial germ cells in the chick embryo Developmental Biology 10 154-190

Moran R, Darzynkiewicz Z, Staiano-Coico L and Melamed MR (1985) Detection of 5-bromodeoxyuridine (BrdUrd) incorporation by monoclonal antibodies: 
role of the DNA denaturation step Journal of Histochemistry and Cytochemistry $33821-827$

Pallavicini MG, Summers LJ, Giroud FJ, Dean PN and Gray JW (1985) Multivariate analysis and list mode processing of murine hemopoietic subpopulations for cytokinetic studies Cytometry 6 539-549

Plickert G and Kroiher M (1988) Proliferation kinetics and cell lineages can be studied in whole mounts and macerates by means of BrdU/anti-BrdU technique Development 103 791-794

Simkiss K, Li Y, Luke G, Page N and Vick L (1993) The production of transgenic birds from primordial germ cell manipulated embryos. In Avian Endocrinology pp $367-380$ Ed. PJ Sharp. Burgess Science Press, Bristol
Soriano E and Del Rio JA (1991) Simultaneous immunocytochemical visualization of bromodeoxyuridine and neural tissue antigens Journal of Histochemistry and Cytochemistry $39255-263$

Swartz WJ and Domm LV (1972) A study on division of primordial germ cells in the early chick embryo American Journal of Anatomy 135 51-70

Vallisneri M, Quaglia A, Stagni AM and Zaccanti F (1990) Differences between male and female protogonia in chick embryos before sex differentiation of the gonads Bollettino Societa Italiana Biologia Sperimentale $6691-98$

Watanabe T and Raff MC (1988) Retinal astrocytes are immigrants from the optic nerve Nature $332834-837$ 